\title{
Blood pressure lowering and major cardiovascular events in people with and without chronic kidney disease: meta-analysis of randomised controlled trials
}

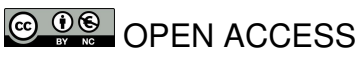

\author{
Blood Pressure Lowering Treatment Trialists' Collaboration
}

\begin{abstract}
Objective To define the cardiovascular effects of lowering blood pressure in people with chronic kidney disease.

Design Collaborative prospective meta-analysis of randomised trials.

Data sources and eligibility Participating randomised trials of drugs to lower blood pressure compared with placebo or each other or that compare different blood pressure targets, with at least 1000 patient years of follow-up per arm.
\end{abstract}

Main outcome measures Major cardiovascular events (stroke, myocardial infarction, heart failure, or cardiovascular death) in composite and individually and all cause death.

Participants 26 trials (152 290 participants), including 30295 individuals with reduced estimated glomerular filtration rate (eGFR), which was defined as eGFR $<60 \mathrm{~mL} / \mathrm{min} / 1.73 \mathrm{~m}^{2}$.

Data extraction Individual participant data were available for 23 trials, with summary data from another three. Meta-analysis according to baseline kidney function was performed. Pooled hazard ratios per $5 \mathrm{~mm}$ $\mathrm{Hg}$ lower blood pressure were estimated with a random effects model.

Results Compared with placebo, blood pressure lowering regimens reduced the risk of major cardiovascular events by about a sixth per 5 $\mathrm{mm} \mathrm{Hg}$ reduction in systolic blood pressure in individuals with (hazard ratio $0.83,95 \%$ confidence interval 0.76 to 0.90 ) and without reduced eGFR $(0.83,0.79$ to 0.88$)$, with no evidence for any difference in effect ( $P=1.00$ for homogeneity). The results were similar irrespective of whether blood pressure was reduced by regimens based on angiotensin converting enzyme inhibitors, calcium antagonists, or diuretics/ $\beta$ blockers. There was no evidence that the effects of different drug classes on major cardiovascular events varied between patients with different eGFR (all $\mathrm{P}>0.60$ for homogeneity).

Conclusions Blood pressure lowering is an effective strategy for preventing cardiovascular events among people with moderately reduced eGFR. There is little evidence from these overviews to support the preferential choice of particular drug classes for the prevention of cardiovascular events in chronic kidney disease.

\section{Introduction}

Chronic kidney disease, most commonly defined by a reduced glomerular filtration rate (GFR) or abnormal concentrations of proteinuria, or both, is an important public health problem, affecting $10-15 \%$ of the adult general population. ${ }^{1-3}$ It is associated with an increased risk of kidney failure and cardiovascular disease. ${ }^{4-6}$ Individuals with early chronic kidney disease are more likely to experience a cardiovascular event than kidney failure, ${ }^{7}$ and precise and reliable evidence about the effects of strategies to prevent cardiovascular disease in this large population of patients is of great importance.

Blood pressure is an important determinant of the risk of cardiovascular disease in the general population. ${ }^{8}$ It is well established that interventions that lower blood pressure prevent cardiovascular events. ${ }^{9}{ }^{10}$ Blood pressure is commonly raised in individuals with chronic kidney disease, ${ }^{56}$ and guidelines recommend lower blood pressure targets in this population than in people without chronic kidney disease. ${ }^{11}{ }^{12}$ Several studies have also suggested particular benefits of drug classes acting through the renin-angiotensin system for the prevention of renal complications. ${ }^{13}$ The evidence that lowering blood pressure is beneficial for patients with chronic kidney disease as well as those without, however, remains limited, and the comparative efficacy of different regimens to lower blood pressure on the risk of cardiovascular events in patients with and without chronic kidney disease remains uncertain. ${ }^{14-19}$

The Blood Pressure Lowering Treatment Trialists' Collaboration $^{20}$ was established to perform a series of prospectively defined overviews of randomised trials to investigate the effects of blood pressure lowering drugs on cardiovascular morbidity and mortality, including assessments of the comparative effects of regimens between major patient subgroups. This analysis, prespecified in the original collaboration protocol, ${ }^{20}$ quantifies the proportional benefits of blood pressure lowering, and the comparative effects of different 
classes of blood pressure lowering drugs in individuals with and without chronic kidney disease.

\section{Methods \\ Data sources and study selection}

Trials were eligible for inclusion in this prospective collaborative meta-analysis if they met one of the following criteria: patients were randomised to a blood pressure lowering drug/regimen or a control group (placebo or less intensive blood pressure lowering regimen) or patients were randomised between regimens based on different classes of drugs to lower blood pressure. Trials were also required to have a minimum of 1000 patient years of planned follow-up in each randomised arm and not to have presented or published their main results before finalisation of the overview protocol in July $1995 .{ }^{20}$ The collaboration was jointly established by the principal investigators in 1995, and the inclusion criteria for the overviews ${ }^{20}$ specified that results of trials reported only after this time could be included. In the early years of the collaboration, participants contributed aggregate trial data but, over time, agreed to provide individual patient data. New trials were identified by a range of methods including computer aided literature searches, scrutiny of abstracts and proceedings of meeting, and by inquiring among colleagues, collaborators, and the manufacturers of antihypertensive drugs. Determination of eligibility was based on a review of details of the study design and quality of the study, regardless of main results of each trial (appendix table 1). The principal investigators for eligible trials were invited to join the collaboration as they were identified. Trials for which data by kidney function had been obtained by April 2012 were included in these analyses. For this overview, data were available from 26 trials providing either individual participant data including serum creatinine concentrations (23 trials $^{21-44}$ ) or summary data stratified by estimated glomerular filtration rate (tabular data from two trials ${ }^{15} 45$ and published hazard ratios from one trial ${ }^{14}$ ). Among them, 25 trials $^{14} 1521-44$ were included in the main analyses, while one trial ${ }^{45}$ contributed participants only to the reduced eGFR stratum and was included in sensitivity analyses. Data regarding urinary protein excretion at baseline were available for 11 trials. $.^{22} 2427-323740$ Two trials ${ }^{15439}$ did not provide information regarding the combined endpoint of major cardiovascular events according to chronic kidney disease status but provided data for other endpoints. The individual participant data requested included characteristics of participants recorded at screening or randomisation, selected measurements during follow-up, and details of all outcomes during the scheduled follow-up period. We used the Cochrane Collaboration's tool to assess the risk of bias. ${ }^{46}$

\section{Glomerular filtration rates and proteinuria}

Glomerular filtration rates were estimated with the modification of diet in renal disease formula ${ }^{7}$ :

eGFR $=186.3 \times(\text { serum creatinine } / 88.4)^{-1.154} \times(\text { age })^{-0.203} \times 1.210$ (if black) $\times 0.742$ (if female)

where eGFR is in $\mathrm{mL} / \mathrm{min} / 1.73 \mathrm{~m}^{2}$, age is in years, and serum creatinine is in $\mu \mathrm{mol} / \mathrm{L}$. The participants were divided into two categories of baseline eGFR $\left(\geq 60 \mathrm{~mL} / \mathrm{min} / 1.73 \mathrm{~m}^{2}\right.$ or and $<60$ $\mathrm{mL} / \mathrm{min} / 1.73 \mathrm{~m}^{2}$ ) with established cutpoints recommended in renal guidelines. ${ }^{11}$ Published data from two trials in which kidney function was estimated with the Cockcroft-Gault formula ${ }^{14}$ or 125 -iothalamate clearance ${ }^{45}$ and patients were categorised as having eGFR $<65 \mathrm{~mL} / \mathrm{min}$ and $\geq 65 \mathrm{~mL} / \mathrm{min}$ were deemed sufficiently comparable and included in the main analysis. The presence of proteinuria was defined as any of the following: urinary albumin excretion rate $\mathrm{s}>200 \mu \mathrm{g} / \mathrm{min}$ or $>300 \mathrm{mg} /$ day, urinary albumin concentration $>200 \mathrm{mg} / \mathrm{L}$, urinary albumin creatinine ratio $>300 \mu \mathrm{g} / \mathrm{mg}$, or a urinary protein dipstick test result of $1+$ or greater. ${ }^{7}$ Stages of chronic kidney disease were defined according to the guidelines from the Kidney Disease Outcomes Quality Initiative (K/DOQI). ${ }^{11}$

\section{Outcomes}

The six outcomes were defined according to the international classification of diseases and were prespecified in the collaboration's protocol. ${ }^{20}$ Outcomes were stroke (non-fatal stroke or death from cerebrovascular disease), coronary heart disease (non-fatal myocardial infarction or death from coronary heart disease including sudden death), heart failure (causing death or requiring admission to hospital), cardiovascular death, and total mortality. The main outcome was major cardiovascular events comprising stroke, coronary heart disease, heart failure, and cardiovascular death. Only the first event of the relevant outcome type was included in each analysis.

\section{Treatment comparisons}

The treatment comparisons tested were prespecified in the original protocol. ${ }^{20}$ In the broad group of trials comparing an active treatment and a control, we carried out separate overviews for angiotensin converting enzyme (ACE) inhibitor based regimens versus placebo; calcium antagonist based regimens versus placebo; and more intensive versus less intensive blood pressure lowering regimens. In the broad group of trials comparing different active agents, we carried out separate overviews for ACE inhibitor based regimens versus conventional treatment (diuretics or $\beta$ blocker based regimens); calcium antagonist based regimens versus conventional treatment; and ACE inhibitor based regimens versus calcium antagonist based regimens.

\section{Data synthesis and analysis Blood pressure reductions}

The reduction in blood pressure in each trial arm was calculated as the mean of the difference between each participant's mean blood pressure during follow-up and their blood pressure at baseline. The mean difference in blood pressure between randomised groups was then calculated by subtracting the values for the two arms according to chronic kidney disease status.

\section{Meta-analyses of subgroups according to kidney function.}

To investigate the effects of active treatment compared with placebo, more intensive compared with less intensive regimens, or different drug classes on the outcomes in patients with different baseline eGFR, we performed meta-analyses according to kidney function. All the meta-analyses used a two stage approach whereby the risk estimates were first summarised in each trial and then combined.

For each trial and each outcome, we estimated the risk estimates separately for each subgroup, according to the intention to treat principle. We computed hazard ratios or odds ratios using a Cox proportional hazard regression model (20 trials providing time to event data ${ }^{2124-42}{ }^{44}$ ) or a logistic regression model (three trials in which time to event data were not available 222343 in the 23 trials for which individual patient data were available. Among the three remaining trials for which data were obtained from the investigators or published reports, we estimated the hazard ratios and variances with a Cox model for one trial ${ }^{14}$ and 
calculated the relative risks and its variances from first principles using tabular data for two trials. ${ }^{15}{ }^{45}$ Although hazard ratios, odds ratios, and relative risks are not the same, we have shown the risk estimates as hazard ratios because these risk estimates have similar values under the condition of low incidence rates of outcomes and most risk estimates in this study were hazard ratios. Additionally, we carried out sensitivity analyses to examine the impact of removing the five trials ${ }^{1522} 234345$ in which the hazard ratios were unavailable for the risk estimates from all analyses. Pooled estimates of hazard ratios and 95\% confidence intervals were calculated separately for each subgroup by a random effects model with the method of DerSimonian and Laird. The "metan" routine in Stata was used for pooled estimates. The heterogeneity in treatment effects between trials included for each comparison was estimated with Cochrane's Q and $\mathrm{I}^{2}$. The consistency of treatment effects across the subgroups of chronic kidney disease status was tested with $\chi^{2}$ tests of homogeneity. The potential for publication bias across included trials was evaluated with Begg's test and Egger's test for funnel plot asymmetry with the "metabias" routine (with $\mathrm{P}<0.10$ taken as significant) and the impact of any asymmetry evaluated with the trim and fill analysis ${ }^{47}$ with the "metatrim" routine in Stata.

\section{Blood pressure weighted meta-analyses of subgroups according to kidney function.}

For the meta-analysis weighted blood pressure reduction in the placebo controlled trials, we calculated pooled estimates per 5 $\mathrm{mm} \mathrm{Hg}$ reduction in systolic blood pressure over time as

\section{$\exp \left[5 *\left(\sum \Delta \mathrm{SBPi}^{*} \mathrm{Wi}^{*} \log \mathrm{HRi}\right) / \Sigma \Delta \mathrm{SBPi}^{2} * \mathrm{Wi}\right]$}

where $\Delta \mathrm{SBPi}$ is the mean difference in systolic blood pressure over time between randomised treatment groups and $\log \mathrm{HRi}$ and $\mathrm{Wi}$ are natural log transformed hazard ratios of randomised treatment on each outcome and its inverse variance in trial i. ${ }^{48} 49$ For the head to head comparisons, where much smaller differences in blood pressure were observed, we calculated similar blood pressure weighted estimates per $1 \mathrm{~mm} \mathrm{Hg}$ difference between the randomised groups.

\section{Continuous effects of eGFR}

We tested for interactions between eGFR fitted as a continuous variable and the effects of treatment on the risk of cardiovascular outcomes to maximise statistical power to detect possible differences in the effects of the various regimens according to baseline eGFR. Interactions between blood pressure lowering treatment and eGFR taken as a continuous variable were investigated with Cox proportional hazard regression models or logistic regression models including study treatment, continuous eGFR values, and their interaction term. The regression coefficient for the latter term estimates the log ratio of hazard ratios for comparing treatments, which shows the effect of a unit increase in eGFR on the treatment effect. Twenty three trials contributing individual participant data were included in these analyses. The log ratios of hazard ratio were pooled with a random effects model. The pooled summary was exponentiated to arrive at the overall estimated ratio of hazard ratio for a $10 \mathrm{~mL} / \mathrm{min} / 1.73 \mathrm{~m}^{2}$ decrement in eGFR for each outcome.

\section{Meta-regression analysis according to kidney function}

Meta-regression analyses were conducted to explore the association between the difference in systolic blood pressure at follow-up between randomised groups and the risk estimate for cardiovascular events in different subgroups, where the response variable was the natural log transformed hazard ratio and the explanatory variable was the effect of treatment on blood pressure. This was investigated across trials by using random effects meta-regression models with inverse variance weighting. Analyses were carried out with the "metareg" routine in Stata. We fitted separate regression lines for each subgroup and compared the slopes of these lines to test for a differential effect of systolic blood pressure reduction on risk reduction between subgroups for each outcome by adding an interaction term between subgroup and systolic blood pressure reduction during follow-up to the model.

As trial participants could contribute only once to a given meta-analysis with regard to the comparison of active treatment versus placebo and a given meta-regression analysis, trials with randomisation to three treatment arms ${ }^{21} 3538$ contributed results from only two of the possible three treatment comparisons, with the control arm participants divided randomly between the two comparisons. For similar reasons, for factorial trials that included randomisation to different intensities of blood pressure lowering and randomisation to different drug treatments, ${ }^{3132} 34{ }^{45}$ we included only the results of the randomisation to different intensities of blood pressure lowering.

All statistical analyses were conducted with SAS software for Windows, version 9.1 (SAS Institute, Cary, NC) or Stata, release 9.2 (StataCorp, College Station, TX). In every analysis a $\mathrm{P}<0.05$ was taken to indicate that a result was possibly not due to chance, although each case required careful interpretation, given the large numbers of comparisons made.

\section{Results}

\section{Characteristics of trials, patients included and follow-up blood pressure levels}

Twenty five trials, ${ }^{14} 1521-44$ including 152290 individuals, provided data for these analyses (tables 1,2 , and $3 \Downarrow \Downarrow \Downarrow$ ). The trials involved had a low risk of bias (appendix table 1).

There were 121995 individuals (80\%) with eGFR $\geq 60$ $\mathrm{mL} / \mathrm{min} / 1.73 \mathrm{~m}^{2}$ (mean eGFR 81 (SD 17) $\mathrm{mL} / \mathrm{min} / 1.73 \mathrm{~m}^{2}$ ) and 30295 individuals $(20 \%)$ with eGFR $<60 \mathrm{~mL} / \mathrm{min} / 1.73 \mathrm{~m}^{2}$ (mean $52(\mathrm{SD} 7) \mathrm{mL} / \mathrm{min} / 1.73 \mathrm{~m}^{2}$ ) at baseline (table $4 \Downarrow$ ). Only 439 individuals $(0.3 \%)$ had $\mathrm{eGFR}<30 \mathrm{~mL} / \mathrm{min} / 1.73 \mathrm{~m}^{2}$ at baseline. Individuals with reduced eGFR tended to be older (68 $v 63)$ and were more likely to be women $(60 \% v 40 \%)$ (table 4). Data on urinary protein excretion were available for 37161 individuals, mostly from trials that compared ACE inhibitor based regimens with placebo. Proteinuria was present in 2500 $(7 \%)$ of these individuals, and patients with proteinuria were more likely to be men ( $66 \% v 55 \%)$ and tended to have a higher serum creatinine concentration at baseline $(91 \mu \mathrm{mol} / \mathrm{L} v 86$ $\mu \mathrm{mol} / \mathrm{L})$. The baseline characteristics of each trial included were well balanced between the randomised treatment allocations (appendix table 2). There was some evidence of publication bias (Egger's test $\mathrm{P}=0.05$ ) across the studies (appendix fig 4). A trim and fill analysis, ${ }^{47}$ however, did not change the pooled estimate.

\section{Effects of active treatment compared with placebo in patients with different baseline eGFR}

For major cardiovascular events, allocation to an ACE inhibitor based regimen reduced the risk of a major cardiovascular event by about a sixth (hazard ratio $0.81,95 \%$ confidence interval 0.73 to 0.90 ). This reduction seemed similar irrespective of 
baseline eGFR ( 0.81 ( 0.72 to 0.91 ) for eGFR of $\geq 60$ $\mathrm{mL} / \mathrm{min} / 1.73 \mathrm{~m}^{2} v 0.81$ ( 0.73 to 0.89 ) for eGFR of $<60$ $\mathrm{mL} / \mathrm{min} / 1.73 \mathrm{~m}^{2} ; \mathrm{P}=0.99$ for homogeneity; fig $\left.1 \Downarrow\right)$. There was significant heterogeneity in treatment effect between trials for the subgroup with eGFR $>60 \mathrm{~mL} / \mathrm{min} / 1.73 \mathrm{~m}^{2}(\mathrm{Q}=19.4, \mathrm{df}=8$, $\mathrm{P}=0.01, \mathrm{I}^{2}=59 \%$ ) but not in the subgroup with reduced GFR (see appendix fig 2). Sensitivity analyses that excluded the three trials $^{1522} 23$ in which the hazard ratios were unavailable for the risk estimates did not make any material difference to the findings (hazard ratio 0.80 ( 0.68 to 0.92 ) for eGFR $\geq 60$ and $0.76(0.68$ to 0.85$)$ for eGFR<60).

Calcium antagonist based regimens likewise reduced the risk of major cardiovascular events by about a third, once again with similar effects among individuals with and without reduced eGFR (fig $1 \Downarrow$ ). Similar findings were observed for secondary outcomes (appendix table 3 ).

\section{Blood pressure weighted meta-analysis of effect of active treatment in patients with different baseline eGFR}

To account for different magnitudes of reduction in blood pressure with different drug classes, we also performed a meta-analysis weighted for blood pressure reduction (fig $2 \Downarrow$ ). A $5 \mathrm{~mm} \mathrm{Hg}$ reduction in systolic blood pressure had almost identical effects on major cardiovascular events at different eGFR, with no difference between ACE inhibitor and calcium channel blocker based regimens compared with placebo (fig $2 \Downarrow$ ). As the results for each class of drugs were similar, we undertook a pooled analysis, which showed that these regimens reduced the risk of major cardiovascular events by $17 \%$ per 5 $\mathrm{mm} \mathrm{Hg}$ reduction in systolic blood pressure in both those below and above eGFR of $60 \mathrm{~mL} / \mathrm{min} / 1.73 \mathrm{~m}^{2}$ (hazard ratio $0.83(95 \%$ confidence interval 0.76 to 0.90 ) and 0.83 (0.79 to 0.88 ), respectively). The proportional reductions in major cardiovascular events were also similar when participants were divided into three eGFR categories $(\geq 60,45-59$, and $<45$ $\mathrm{mL} / \mathrm{min} / 1.73 \mathrm{~m}^{2}$ ).

\section{Net absolute effects of treatment in patients with different baseline eGFR}

We investigated the absolute effects of active treatment in patients with eGFR above and below $60 \mathrm{~mL} / \mathrm{min} / 1.73 \mathrm{~m}^{2}$ on the basis of the incidence rates for major cardiovascular events in the placebo groups and the blood pressure weighted hazard ratios of active treatment. Overall, 21 major cardiovascular events were prevented for every 1000 participants treated (ACE inhibitor or calcium channel blocker based regimens) compared with placebo (number needed to treat (NNT) for preventing one event over an average of four years was 47). Although the magnitude of the relative effects of active treatment were similar across eGFR, the absolute benefit for major cardiovascular events was $50 \%$ higher at lower eGFR, with 28 events prevented for every 1000 patients with eGFR below $60 \mathrm{~mL} / \mathrm{min} / 1.73 \mathrm{~m}^{2}$ $(\mathrm{NNT}=35)$ compared with 19 for patients with eGFR above 60 $\mathrm{mL} / \mathrm{min} / 1.73 \mathrm{~m}^{2}(\mathrm{NNT}=53)$.

\section{Effects of more intensive compared with less intensive blood pressure lowering regimens in patients with different baseline eGFR}

As shown in figure $3 \Downarrow$, for the trials targeting different blood pressure goals there were wide confidence intervals but no evidence of heterogeneity of treatment effects on major cardiovascular events according to baseline eGFR (hazard ratio 0.87 ( $95 \%$ confidence interval 0.73 to 1.03 ) for eGFR of $\geq 60$
$\mathrm{mL} / \mathrm{min} / 1.73 \mathrm{~m}^{2} v 1.24$ (0.62 to 2.48 ) for eGFR of $<60$ $\mathrm{mL} / \mathrm{min} / 1.73 \mathrm{~m}^{2} ; \mathrm{P}=0.33$ for homogeneity). The effects of more intensive compared with less intensive regimens for secondary outcomes are shown in appendix table 4 . A sensitivity analysis that included one further tria ${ }^{45}$ that comprised only patients with reduced eGFR made little difference to the findings (1.10 ( 0.76 to 1.60 ) in patients with eGFR $<60 \mathrm{~mL} / \mathrm{min} / 1.73 \mathrm{~m}^{2}$; $\mathrm{P}=0.24$ for heterogeneity).

\section{Effects of different drug classes in patients with different baseline eGFR}

In the trials comparing blood pressure lowering regimens based on different drug classes, there were no clear differential effects on major cardiovascular events (fig $4 \Downarrow$ ) between groups with different eGFR for any comparison (all $\mathrm{P}>0.6$ for homogeneity). The results of the comparisons between calcium antagonist based regimens and conventional treatment after exclusion of one trial ${ }^{43}$ in which the hazard ratios were unavailable for the risk estimates (hazard ratio 1.04 (95\% confidence interval 0.98 to 1.11 ) for eGFR $\geq 60$ and 1.05 ( 0.95 to 1.16$)$ eGFR $<60)$ and the results of the comparisons among different drug classes in participants with eGFR $<60$ after inclusion of one trial ${ }^{45}$ that contributed patients only to the reduced eGFR stratum (1.00 (0.91 to 1.10) for ACE inhibitor $v$ conventional; 1.03 (0.93 to 1.14) for calcium antagonist $v$ conventional; 0.96 (0.86 to 1.08) for ACE inhibitor $v$ calcium antagonist) remained substantially unchanged. The findings were also similar in the blood pressure weighted comparisons (appendix fig 3). For the secondary outcomes, there was heterogeneity in the effect of ACE inhibitor based regimens against heart failure compared with calcium antagonist based regimen by eGFR, with evidence of greater benefit for ACE inhibitors among participants with eGFR $>60$ (appendix table 5).

\section{Interactions between blood pressure lowering treatment and continuous eGFR.}

We found no evidence of a significant interaction between baseline eGFR and treatment effect for major cardiovascular events (all $\mathrm{P}>0.18$, fig $5 \Downarrow$ ). For the secondary outcomes, we observed just two significant interactions between eGFR and treatment among 30 comparisons, suggesting they might have arisen by chance (appendix fig 4).

\section{Association between trial differences in blood pressure and proportional risk reductions}

The association between blood pressure lowering achieved and the proportional reduction in risk of cardiovascular events achieved was similar in participants with reduced compared with normal eGFR when assessed with meta-regression. A 5 $\mathrm{mm} \mathrm{Hg}$ reduction in systolic blood pressure during follow-up was associated with a relative risk reduction of $14.2 \%(95 \%$ confidence interval $8.6 \%$ to $19.5 \%$ ) in participants with normal eGFR and $12.1 \%$ (2.9\% to $20.4 \%$ ) for participants with reduced eGFR for the primary outcome of major cardiovascular events $(\mathrm{P}=0.69$ for homogeneity) (fig $6 \Downarrow$ ).

\section{Effects of active treatment compared with placebo in patients with and without proteinuria at baseline}

There was no evidence of heterogeneity $(\mathrm{P}=0.84$ for homogeneity) in the effect of ACE inhibitor based regimens on major cardiovascular events between individuals with (hazard ratio $0.94,95 \%$ confidence interval 0.84 to 1.05 ) and without proteinuria $(0.90,0.63$ to 1.29$)$ per $5 \mathrm{~mm} \mathrm{Hg}$ reduction in 
systolic blood pressure, although only limited data were available (fig $7 \Downarrow$ ). There were not enough trials with data on proteinuria to allow reliable assessment of the comparative effects of calcium antagonists, different blood pressure targets, and different drug classes in patients with and without proteinuria.

\section{Discussion \\ Principal findings}

These analyses, based on a large volume of data with several trials that included people who did not have hypertension, provide compelling evidence for the cardiovascular benefits of reduction in blood pressure in people with stage 1-3 chronic kidney disease. While the proportional reductions in the risk of major cardiovascular events were similar in people with and without evidence of chronic kidney disease, individuals with chronic kidney disease stood to gain much larger absolute benefits because their baseline risk was much higher. The high prevalence of chronic kidney disease in the community (10-15\%) means that strategies to increase the use of blood pressure lowering treatments among this group are likely to be highly effective at reducing the burden of cardiovascular mortality and morbidity. ${ }^{561416}$

\section{Effect of different drug classes on cardiovascular events in people with chronic kidney disease}

The data provided no clear evidence that any particular drug class provided greater or lesser cardiovascular protection for patients with compared with those without chronic kidney disease. This was true both for subgroup analyses done by dichotomising patients according to usual eGFR cutpoints and for the more powerful analyses done with eGFR fitted as a continuous variable. Intriguingly, the cardiovascular benefits of ACE-I and calcium channel blockers compared with placebo were virtually identical once we accounted for the small differences in blood pressure lowering achieved in analyses weighted for blood pressure reduction, although different types of calcium channel blockers were used in these analysis, including dihydropyridines (such as amlodipine and nisoldipine) and phenylalkylamines (such as verapamil). Similar findings were observed in the meta-regression analyses and in head to head comparisons that also included diuretics or $\beta$ blockers. These results suggest that the cardiovascular benefits of lowering blood pressure in people with chronic kidney disease are more dependent on the blood pressure lowering effect achieved than on the agent selected. This is an observation broadly consistent with the previously reported findings across the trial populations, ${ }^{9}$ although small benefits independent of blood pressure reduction have been reported for ACE inhibitors and coronary heart disease. ${ }^{50}$ Additionally, a recent randomised control trial in patients with hypertension showed that treatment with benazepril plus amlodipine was superior to that with benazepril plus hydrochlorothiazide in preventing cardiovascular events, despite no clear difference in the achieved blood pressure during follow-up. ${ }^{51}$ Several studies have also suggested that drugs acting via the renin-angiotensin system provide greater protection against renal outcomes, but we did not assess these outcomes. ${ }^{13}$ It is therefore possible there might be additional benefits (or harms) independent of blood pressure associated with individual classes of drugs, but this analysis highlights the key role of blood pressure lowering as a driver of reduction in cardiovascular risk. Future analyses including data from completed and ongoing trials should clarify whether greater effects on renal outcomes achieved by these drug classes in patients with proteinuria will translate into greater protection against major vascular events

\section{Effects of intensive blood pressure lowering on cardiovascular events in chronic kidney disease}

There was no clear benefit for more intensive compared with less intensive blood pressure lowering regimens in people with chronic kidney disease, although there was only limited power for these analyses and little capacity to detect whether the effects of treatment varied according to kidney function; lower blood pressure targets have, nonetheless, been suggested to improve renal outcomes in people with proteinuric chronic kidney disease, ${ }^{52} 53$ providing some support for the earlier recommendation that blood pressure be lowered more intensively in these high risk patients. The effects of more intensive blood pressure lowering on cardiovascular outcomes in people with kidney disease remains to be demonstrated by future trials, such as the ongoing Systolic Blood Pressure Intervention Trial (SPRINT, NCT01206062).

\section{Strengths and weaknesses}

These analyses, based on more than 150000 trial participants and 15000 major cardiovascular events, are uniquely powerful and provide precise estimates of the effects on major cardiovascular events of the most widely used regimens to lower blood pressure in patients with and without chronic kidney disease. There are, however, several important limitations. Firstly, most participants with chronic kidney disease in this study were in stage $3 a$ (mostly in the range of 45-60 $\left.\mathrm{mL} / \mathrm{min} / \mathrm{m}^{2}\right)$, and few participants $(0.4 \%)$ had eGFR $\leq 30$ $\mathrm{mL} / \mathrm{min} / 1.73 \mathrm{~m}^{2}$. As a result, the applicability of these results to populations with stage 4-5 disease is uncertain, although they are broadly consistent with a meta-analysis of blood pressure lowering in patients with severe kidney disease who were receiving dialysis ${ }^{54}$ Likewise, few participants had documented proteinuria and only limited numbers of events were available in this population group. Secondly, the analyses depend on the trial data that were available at the start of this study and we could not investigate some questions of interest. These include the effects on cardiovascular outcomes of regimens based on angiotensin receptor blockers and the separate evaluation of regimens based on $\beta$ blockers or diuretics alone. When possible, we contacted investigators directly to request missing data or extracted data from published reports to complement available data. Therefore, while we acknowledge this is not a complete dataset, we believe selection bias in this study is minimised by the strict pre-specification of trial eligibility criteria including those related to trial size, quality, randomisation process, outcome definition, treatment comparison, and analysis as specified the published study protocol. ${ }^{20}$ Furthermore, and in line with recommendations for reporting individual patient data meta-analyses where there are missing data, ${ }^{55}$ we formally assessed publication bias in this study. We found some evidence of publication bias, which is likely to overestimate the pooled treatment effects, although a trim and fill analysis did not change the pooled estimate. Thirdly, we collected data based on the MDRD-GFR equation from the collaborators as the CKD-EPI equation had not yet been reported when the collaboration was first established. Indeed, it has been suggested that the CKD-EPI equation might be superior to the MDRD-GFR equation for estimating GFR in people with eGFR of $\geq 60 \mathrm{~mL} / \mathrm{min} / 1.73 \mathrm{~m}^{2}$, but both equations have similar accuracy in people with eGFR of $<60 \mathrm{~mL} / \mathrm{min} / 1.73 \mathrm{~m}^{2}$. ${ }^{56}$ As we divided into only two 
categories, below and above $60 \mathrm{~mL} / \mathrm{min} / 1.73 \mathrm{~m}^{2}$, rather than the detailed categories of eGFR, we believe this issue would be unlikely to have an important impact on the findings. Finally, uncertainty in estimation of the reduction in blood pressure in each trial will reduce the accuracy of estimation of the treatment effect of blood pressure lowering on cardiovascular risk.

\section{Conclusions}

These overviews provide clear evidence that a broad range of different blood pressure lowering regimens provide protection against cardiovascular complications in patients with and without chronic kidney disease. Specifically, blood pressure lowering per se, not the effects of a particular drug class (such as renin-angiotensin system blockade), seems to be significantly associated with lower cardiovascular risk in early stage chronic kidney disease, possibly suggesting the importance of blood pressure lowering as a driver of cardiovascular risk reduction. These findings should help to guide decision making for many physicians and their patients, given the absence of clear evidence to date supporting recommendations (for particular drug classes) to reduce the cardiovascular risk among people with early stage chronic kidney disease. As people with chronic kidney disease are at greatly increased cardiovascular risk, the benefits of blood pressure lowering in this population are large. The broader use of blood pressure lowering drugs, along with other proved treatments such as lipid lowering ${ }^{57}$ will both improve outcomes for affected individuals and help to reduce the escalating global burden of cardiovascular disease.

Members of the blood pressure lowering treatment trialists' collaboration L Agodoa, C Anderson, FW Asselbergs, C Baigent, H Black, B Brenner, M Brown, C Bulpitt, R Byington, J Chalmers, R Collins, J Cutler, B Dahlof, B Davis, D de Zeeuw, J Dens, R Estacio, R Fagard, K Fox, T Fukui, L Hansson (deceased), R Holman, L Hunsicker, Y Imai, M Ishii, Y Kanno, J Kostis, K Kuramoto, E Lewis, M Lièvre, L H Lindholm, L Liu, J Lubsen, S Lueders, S MacMahon, E Malacco, G Mancia, M Matsuzaki, B Neal, S Nissen, T Ohkubo, T Ogihara, C Pepine, M Pfeffer, B Pitt, P Poole-Wilson (deceased), N Poulter, M Rahman, W Remme, G Remuzzi, A Rodgers, P Ruggenenti, T Saruta, J Schrader, R Schrier, P Sever, P Sleight, J Staessen, H Suzuki, K Teo, WH van Gilst, G Viberti, J Wang, P Whelton, L Wing, Y Yui, S Yusuf, A Zanchetti.

Collaboration coordinating centre

F Barzi, J Chalmers, S Heritier, N Li, S MacMahon, B Neal, T Ninomiya, V Perkovic, F Turnbull, M Woodward. Renal Working Group: C Baigent (Chair), V Perkovic, F Turnbull, K Wilson, A Cass, P Kearney, M Gallagher, L Agodoa, B Brenner, L Hunsicker, M Rahman, G Remuzzi, $P$ Ruggenenti, $P$ Whelton.

Writing committee

T Ninomiya, V Perkovic, F Turnbull, B Neal, F Barzi, A Cass, C Baigent, J Chalmers, N Li, M Woodward, S MacMahon.

Contributors: TN contributed to the study design, data management, statistical analysis, and data interpretation, and wrote the first draft of the manuscript and is guarantor. VP and CB coordinated and led the development of this paper, contributed to the study concept and design, data interpretation, and drafting of the manuscript. FT and NL contributed to the data collection, data management, and critical revision. AC contributed to the critical revision of the manuscript. FB provided support for the statistical analysis and contributed to the critical revision of the manuscript. MW contributed to the study concept, data collection,

support of the statistical analysis, and critical revision of the manuscript. $\mathrm{BN}, \mathrm{JC}$, and SMacM contributed to the study concept, data collection, and critical revision of the manuscript.

Funding: This project was funded by the National Health and Medical Research Council of Australia. The funding body had no input into the design, conduct or interpretation of the study. T Ninomiya was supported by a fellowship awarded by the Banyu Life Science Foundation and by an International Society of Hypertension Visiting Postdoctoral Fellowship awarded by the Foundation for High Blood Pressure Research Council of Australia. V Perkovic was supported by a National Health and Medical Research Council program grant and a Heart Foundation of Australia Career Development Fellowship. F Turnbull was supported by a National Heart Foundation of Australia Career Development Fellowship. A Cass was supported by National Health and Medical Research Council of Australia Senior and Principal Research Fellowships. B Neal was supported by fellowships awarded by the Australian Research Council and the National National Health and Medical Research Council of Australia, and the Collaboration Coordinating Centre by Program and Project Grants provided by the National Health and Medical Research Council of Australia. N Li was supported by a Fogarty International Clinical Research Fellowship and National Health and Medical Research Council Australia-China Exchange Fellowship.

Competing interests: All authors have completed the ICMJE uniform disclosure form at www.icmje.org/coi_disclosure.pdf (available on request from the corresponding author) and declare: VP has received honoraria from Astra Zeneca, Merck, and Servier for scientific presentations and is a trial steering committee and/or advisory board member for Abbvie, Astellas, Baxter, Boehringer Ingelheim, Janssen, and Vitae: JC, MW, and SM have received honoraria from Servier for scientific presentations relating to blood pressure; SM and JC were principal investigators on ADVANCE, a blood pressure lowering trial funded by Servier and the Australian National Health and Medical Research Council; BN has received blood pressure related research support from Servier and honoraria for scientific presentations related to blood pressure from Novartis, Tanabe, and Servier.

\section{Ethical approval: Not required.}

Data sharing: Technical appendix, statistical code, and dataset are available from the corresponding author.

1 Perkovic V, Cass A, Patel A, Suriyawongpaisal P, Barzi F, Chadban S, et al; InterASIA Collaborative Group. High prevalence of chronic kidney disease in Thailand. Kidney Int 2008;73:473-9.

2 Chadban SJ, Briganti EM, Kerr PG, Dunstan DW, Welborn TA, Zimmet PZ, et al. Prevalence of kidney damage in Australian adults: the AusDiab kidney study. J Am Soc Nephrol 2003;14(7 suppl 2):S131-8.

3 Coresh J, Astor BC, Greene T, Eknoyan G, Levey AS. Prevalence of chronic kidney disease and decreased kidney function in the adult US population: Third National Health and Nutrition Examination Survey. Am J Kidney Dis 2003:41:1-12.

4 Sarnak MJ, Levey AS, Schoolwerth AC, Coresh J, Culleton B, Hamm LL, et al; American Heart Association Councils on Kidney in Cardiovascular Disease, High Blood Pressure Research, Clinical Cardiology, and Epidemiology and Prevention. Kidney disease as a risk factor for development of cardiovascular disease: a statement from the American Heart Association Councils on Kidney in Cardiovascular Disease, High Blood Pressure Research, Clinical Cardiology, and Epidemiology and Prevention. Circulation 2003;108:2154-69.

5 Go AS, Chertow GM, Fan D, McCulloch CE, Hsu CY. Chronic kidney disease and the risks of death, cardiovascular events, and hospitalization. $N$ Engl J Med 2004;351:1296-305.

6 Manjunath G, Tighiouart H, Ibrahim H, MacLeod B, Salem DN, Griffith JL, et al. Level of kidney function as a risk factor for atherosclerotic cardiovascular outcomes in the community. J Am Coll Cardiol 2003;41:47-55.

7 Sarnak MJ, Levey AS, Schoolwerth AC, Coresh J, Culleton B, Hamm LL, et al; American Heart Association Councils on Kidney in Cardiovascular Disease, High Blood Pressure Research, Clinical Cardiology, and Epidemiology and Prevention. Kidney disease as a risk factor for development of cardiovascular disease: a statement from the American Heart Association Councils on Kidney in Cardiovascular Disease, High Blood Pressure Research, Clinical Cardiology, and Epidemiology and Prevention. Circulation 2003;108:2154-69.

8 MacMahon S, Peto R, Cutler J, Collins R, Sorlie P, Neaton J, et al. Blood pressure, stroke, and coronary heart disease. Part 1. Prolonged differences in blood pressure: prospective observational studies corrected for the regression dilution bias. Lancet 1990;335:765-74.

9 Blood Pressure Lowering Treatment Trialists' Collaboration. Effects of different blood-pressure-lowering regimens on major cardiovascular events: results of
prospectively-designed overviews of randomised trials. Lancet 2003;362:1527-35.

10 Lawes CM, Bennett DA, Feigin VL, Rodgers A. Blood pressure and stroke: an overview of published reviews. Stroke 2004;35:1024-33.

$11 \mathrm{~K} / \mathrm{DOQI}$ clinical practice guidelines for chronic kidney disease. Evaluation, classification, and stratification. Am J Kidney Dis 2002;39(2 suppl 1):S1-S266.

12 Chobanian AV, Bakris GL, Black HR, Cushman WC, Green LA, Izzo JL Jr, et al; Joint National Committee on Prevention, Detection, Evaluation, and Treatment of High Blood Pressure. National Heart, Lung, and Blood Institute; National High Blood Pressure Education Program Coordinating Committee: Seventh report of the Joint National Committee on Prevention, Detection, Evaluation, and Treatment of High Blood Pressure. Hypertension 2003;42:1206-52. 


\section{What is already known on this topic}

Blood pressure is commonly raised in people with chronic kidney disease

Guidelines recommend lower blood pressure targets in these people, though there is limited evidence that blood pressure lowering is beneficial for people with chronic kidney disease

The comparative efficacy of different classes of drug to lower blood pressure on the risk of cardiovascular events in people with chronic kidney disease also remains uncertain

\section{What this study adds}

The proportional reductions of cardiovascular complications in risk with lowered blood pressure are similar in people with and without chronic kidney disease, but people with kidney disease gain much larger absolute benefits because their baseline risk is higher There is little evidence to support the preferential choice of particular drug classes for the prevention of cardiovascular events in people with chronic kidney disease

13 Strippoli GF, Bonifati C, Craig M, Navaneethan SD, Craig JC. Angiotensin converting enzyme inhibitors and angiotensin II receptor antagonists for preventing the progression of diabetic kidney disease. Cochrane Database Syst Rev . 2006;18:CD006257.

14 Mann JF, Gerstein HC, Pogue J, Bosch J, Yusuf S. Renal insufficiency as a predictor of cardiovascular outcomes and the impact of ramipril: the HOPE randomized trial. Ann Intern Med 2001;134:629-36

15 Solomon SD, Rice MM, A Jablonski K, Jose P, Domanski M, Sabatine M, et al; Prevention of Events with ACE inhibition (PEACE) Investigators. Renal function and effectiveness of angiotensin-converting enzyme inhibitor therapy in patients with chronic stable coronary disease in the Prevention of Events with ACE inhibition (PEACE) trial. Circulation 2006;114:26-31.

16 Perkovic V, Ninomiya T, Arima H, Gallagher M, Jardine M, Cass A, et al. Chronic kidney disease, cardiovascular events, and the effects of perindopril-based blood pressure lowering: data from the PROGRESS study. J Am Soc Nephrol 2007;18:2766-72.

17 Brenner BM, Cooper ME, de Zeeuw D, Keane WF, Mitch WE, Parving HH, et al; RENAAL Study Investigators. Effects of losartan on renal and cardiovascular outcomes in patients with type 2 diabetes and nephropathy. N Engl J Med 2001;345:861-9.

18 Lewis EJ, Hunsicker LG, Clarke WR, Berl T, Pohl MA, Lewis JB, et al; Collaborative Study Group. Renoprotective effect of the angiotensin-receptor antagonist irbesartan in patients with nephropathy due to type 2 diabetes. N Engl J Med 2001;345:851-60.

19 Agodoa LY, Appel L, Bakris GL, Beck G, Bourgoignie J, Briggs JP, et al; African American Study of Kidney Disease and Hypertension (AASK) Study Group. Effect of ramipril vs amlodipine on renal outcomes in hypertensive nephrosclerosis: a randomized controlled trial. JAMA 2001:285-2719-28.

20 Protocol for prospective collaborative overviews of major randomized trials of blood-pressure lowering treatments. World Health Organization-International Society of Hypertension Blood Pressure Lowering Treatment Trialists' Collaboration. $J$ Hypertens 1998;16:127-37.

21 Ruggenenti P, Fassi A, llieva AP, Bruno S, lliev IP, Brusegan V, et al; Bergamo Nephrologic Diabetes Complications Trial (BENEDICT) Investigators. Preventing microalbuminuria in type 2 diabetes. N Engl J Med . 2004;351:1941-51.

22 Marre M, Lievre M, Chatellier G, Mann JF, Passa P, Ménard J; DIABHYCAR Study Investigators. Effects of low dose ramipril on cardiovascular and renal outcomes in patients with type 2 diabetes and raised excretion of urinary albumin: randomised, double blind, placebo controlled trial (the DIABHYCAR study). BMJ 2004;328:495.

23 The European trial on reduction of cardiac events with perindopril in stable coronary artery disease investigators. Efficacy of perindopril in reduction of cardiovascular events among patients with stable coronary artery disease: randomised, double-blind, placebo-controlled, multicentre trial (the EUROPA study). Lancet 2003;362:782-8.

24 MacMahon S, Sharpe N, Gamble G, Clague A, Mhurchu CN, Clark T, et al. Randomised, placebo-controlled trial of the angiotensin converting enzyme inhibitor, ramipril, in patients with coronary or other occlusive vascular disease. J Am Coll Cardiol 2000;36:438-43.

25 PROGRESS Collaborative Group. Randomised trial of a perindopril-based blood pressure lowering regimen among 6,105 individuals with previous stroke or transient ischaemic attack. Lancet 2001;358:1033-41.

26 Teo KK, Burton JR, Buller CE, Plante S, Catellier D, Tymchak W, et al. Long-term effects of cholesterol lowering and angiotensin-converting enzyme inhibition on coronary atherosclerosis. The Simvastatin/enalapril Coronary Atherosclerosis Trial (SCAT). Circulation 2000;102:1748-54.

27 Asselbergs FW, Diercks GF, Hillege HL, van Boven AJ, Janssen WM, Voors AA, et al Prevention of Renal and Vascular Endstage Disease Intervention Trial (PREVEND IT) Investigators. Effects of fosinopril and pravastatin on cardiovascular events in subjects with microalbuminuria. Circulation 2004;110:2809-16.

28 Patel A, MacMahon S, Chalmers J, Neal B, Woodward M, Billot L, et al. ADVANCE Collaborative Group. Effects of a fixed combination of perindopril and indapamide on macrovascular and microvascular outcomes in patients with type 2 diabetes mellitus (the ADVANCE trial): a randomised controlled trial. Lancet 2007;370:829-40.

29 Pitt B, Byington RP, Furberg CD, Hunninghake DB, Mancini GB, Miller ME, et al. Effect of amlodipine on the progression of atherosclerosis and the occurrence of clinical events. Circulation 2000;102:1503-10.

30 Staessen JA, Fagard R, Thijs L, Celis H, Arabidze GG, Birkenhäger WH, et al. Randomised double-blind comparison of placebo and active treatment for older patients with isolated systolic hypertension in Europe. Lancet 1997;350:757-64.

31 Estacio R, Jeffers B, Hiatt W, Biggerstaff S, Gifford N, Schrier R. The effect of nisoldipine as compared with enalapril on cardiovascular outcomes in patients with non-insulin dependent diabetes and hypertension. N Engl J Med . 1998;338:645-52.

32 Schrier R, Estacio R, Esler A, Mehler P. Effects of aggressive blood pressure control in normotensive type 2 diabetic patients on albuminuria, retinopathy and strokes. Kidney Int . 2002;61:1086-97.

33 Hansson L, Zanchetti A, Carruthers SG, Dahlöf B, Elmfeldt D, Julius S, et al. Effects of intensive blood-pressure lowering and low-dose aspirin in patients with hypertension: principal results of the Hypertension Optimal Treatment (HOT) randomised trial. Lancet 1998;351:1755-62
34 UK Prospective Diabetes Study Group. Tight blood pressure control and risk of macrovascular and microvascular complications in type 2 diabetes: UKPDS 38. BMJ 1998;317:703-13.

35 ALLHAT Officers and Coordinators for the ALLHAT Collaborative Research Group. Majo outcomes in high-risk hypertensive patients randomized to angiotensin-converting enzyme inhibitor or calcium channel blocker vs diuretic. JAMA 2002;288:2981-97.

36 Wing LM, Reid CM, Ryan P, Beilin LJ, Brown MA, Jennings GL, et al; Second Australian National Blood Pressure Study Group. A comparison of outcomes with angiotensin-converting-enzyme inhibitors and diuretics for hypertension in the elderly. $N$ Engl J Med . 2003:348:583-92.

37 Hansson L, Lindholm LH, Niskanen L, Lanke J, Hedner T, Niklason A, et al. Effect of angiotensin converting enzyme inhibition compared with conventional therapy on cardiovascular morbidity and mortality in hypertension: the Captopril Prevention Project (CAPPP) randomised trial. Lancet 1999;353:611-6.

38 Hansson L, Lindholm LH, Ekbom T, Dahlöf B, Lanke J, Scherstén B, et al. Randomised trial of old and new antihypertensive drugs in elderly patients: cardiovascular mortality and morbidity the Swedish Trial in Old Patients with Hypertension-2 study. Lancet 1999;354:1751-6.

39 UK Prospective Diabetes Study Group. Efficacy of atenolol and captopril in reducing risk of macrovascular and microvascular complications in type 2 diabetes: UKPDS 39. BMJ 1998;317:713-20

40 Zanchetti A, Bond MG, Hennig M, Neiss A, Mancia G, Dal Palù C, et al; European Lacidipine Study on Atherosclerosis investigators. Calcium antagonist lacidipine slows down progression of asymptomatic carotid atherosclerosis. Circulation 2002;106:2422-7.

41 National Intervention Cooperative Study in Elderly Hypertensives Study Group. Randomized double-blind comparison of a calcium antagonist and a diuretic in elderly hypertensives. Hypertension 1999;34:1129-33.

42 Hansson L, Hedner T, Lund-Johansen P, Kjeldsen SE, Lindholm LH, Syvertsen JO, et al. Randomised trial of effects of calcium antagonists compared with diuretics and beta-blockers on cardiovascular morbidity and mortality in hypertension: the Nordic Diltiazem (NORDIL) study. Lancet 2000;356:359-65.

43 Zanchetti A, Agabiti-Rosei E, Dal Palu C, Leonetti G, Magnani B, Pessina A. The Verapamil in Hypertension and Atherosclerosis Study (VHAS): results of long-term randomised treatment with either verapamil or chlorthalidone on intima-media thickness. $J$ Hypertens 1998;16:1667-76

44 Yui Y, Sumiyoshi T, Kodama K, Hirayama A, Nonogi H, Kanmatsuse K, et al; Japan Multicenter Investigation for Cardiovascular Diseases-B Study Group. Comparison of nifedipine retard with angiotensin converting enzyme inhibitors in Japanese hypertensive patients with coronary artery disease: the Japan Multicenter Investigation for Cardiovascular Diseases-B (JMIC-B) randomized trial. Hypertens Res 2004;27:181-91.

45 Wright JT Jr, Bakris G, Greene T, Agodoa LY, Appel LJ, Charleston J, et al; African American Study of Kidney Disease and Hypertension Study Group. Effect of blood pressure lowering and antihypertensive drug class on progression of hypertensive kidney disease: results from the AASK trial. JAMA 2002;288:2421-31.

46 Cochrane Collaboration's tool for assessing risk of bias. http://ohg.cochrane.org/sites/ ohg.cochrane.org/files/uploads/Risk\%20of\%20bias\%20assessment\%20tool.pdf.

47 Duval S, Tweedie R. Trim and fill: A simple funnel-plot-based method of testing and adjusting for publication bias in meta-analysis. Biometrics 2000;56:455-63.

48 Baigent C, Keech A, Kearney PM, Blackwell L, Buck G, Pollicino C, Kirby A, Sourjina T, Peto R, Collins R, Simes R; Cholesterol Treatment Trialists' (CTT) Collaborators. Efficacy and safety of cholesterol-lowering treatment: prospective meta-analysis of data from 90,056 participants in 14 randomised trials of statins. Lancet 2005;366:1267-78.

49 Tierney JF, Stewart LA, Ghersi D, Burdett S, Sydes MR. Practical methods for incorporating summary time-to-event data into meta-analysis. Trials 2007;8:16.

50 Blood Pressure Lowering Treatment Trialists' Collaboration. Blood pressure-dependent and independent effects of agents that inhibit the renin-angiotensin system. $J$ Hypertens 2007;25:951-8.

51 Jamerson K, Weber MA, Bakris GL, Dahlöf B, Pitt B, Shi V, et al; ACCOMPLISH Trial nvestigators. Benazepril plus amlodipine or hydrochlorothiazide for hypertension in high-risk patients. N Engl J Med 2008:359:2417-28

52 Appel LJ, Wright JT Jr, Greene T, Agodoa LY, Astor BC, Bakris GL, et al; AASK Collaborative Research Group. Intensive blood-pressure control in hypertensive chronic kidney disease. N Engl J Med 2010;363:918-29

53 Sarnak MJ, Greene T, Wang X, Beck G, Kusek JW, Collins AJ, et al. The effect of a lowe target blood pressure on the progression of kidney disease: long-term follow-up of the modification of diet in renal disease study. Ann Intern Med 2005;142:342-51.

54 Heerspink HJ, Ninomiya T, Zoungas S, de Zeeuw D, Grobbee DE, Jardine MJ, et al. Effect of lowering blood pressure on cardiovascular events and mortality in patients on dialysis: a systematic review and meta-analysis of randomised controlled trials. Lancet 2009;373:1009-15

55 Ahmed I, Sutton AJ, Riley RD. Assessment of publication bias, selection bias, and unavailable data in meta-analyses using individual participant data: a database survey. BMJ 2012;344:d7762.

56 Levey AS, Stevens LA, Schmid CH, Zhang YL, Castro AF 3rd, Feldman HI, Kusek JW, Eggers P, Van Lente F, Greene T, Coresh J; CKD-EPI (Chronic Kidney Disease 
Epidemiology Collaboration). A new equation to estimate glomerular filtration rate. Ann Intern Med 2009;150:604-12

57 SHARP Investigators. The effects of lowering LDL cholesterol with simvastatin plus ezetimibe in patients with chronic kidney disease (Study of Heart and Renal Protection): a randomised placebo-controlled trial. Lancet 2011;377:2181-92.

Accepted: 23 August 2013
Cite this as: BMJ 2013;347:f5680

This is an Open Access article distributed in accordance with the Creative Commons Attribution Non Commercial (CC BY-NC 3.0) license, which permits others to distribute, remix, adapt, build upon this work non-commercially, and license their derivative works on different terms, provided the original work is properly cited and the use is non-commercial. See: http://creativecommons.org/licenses/by-nc/3.0/. 


\section{Tables}

Table 1 | Characteristics of included double blind trials comparing active treatment for blood pressure control and placebo in patients with chronic kidney disease

\begin{tabular}{|c|c|c|c|c|c|c|c|c|}
\hline Trial & $\begin{array}{l}\text { Treatment } \\
\text { comparison }\end{array}$ & No $^{*}$ & Entry criteria & $\begin{array}{l}\text { Kidney function } \\
\text { exclusion criteria }\end{array}$ & $\begin{array}{l}\text { Follow-up } \\
\text { (years) }\end{array}$ & $\begin{array}{l}\text { Mean (SD) eGFR } \\
\left(\mathrm{mL} / \mathrm{min} / 1.73 \mathrm{~m}^{2}\right)\end{array}$ & $\begin{array}{l}\text { No (\%) with } \\
\text { eGFR <60 }\end{array}$ & $\begin{array}{l}\text { No }(\%) \text { with } \\
\text { proteinuria }\end{array}$ \\
\hline \multicolumn{9}{|c|}{ ACE inhibitor $v$ placebo } \\
\hline BENEDICT $^{21}$ & Trandolapril $v$ placebo & 604 & $\mathrm{HBP}+\mathrm{DM}$ & $\mathrm{sCr}>133 \mu \mathrm{mol} / \mathrm{L}$ & 3.6 & $81(15)$ & $37(6)$ & $0(0) \dagger$ \\
\hline DIAB-HYCAR ${ }^{22}$ & Ramipril $v$ placebo & 4912 & DM+nephropathy & $\mathrm{sCr}>150 \mu \mathrm{mol} / \mathrm{L}$ & 3.9 & $77(21)$ & $999(20)$ & $1286(26) \ddagger$ \\
\hline EUROPA $^{23}$ & Perindopril $v$ placebo & 12218 & $\mathrm{CHD}$ & $\mathrm{sCr}>150 \mu \mathrm{mol} / \mathrm{L}$ & 4.2 & $75(18)$ & $1999(17)$ & NA \\
\hline $\mathrm{HOPE}^{14}$ & Ramipril $v$ placebo & 9297 & $\begin{array}{l}\text { CHD, CVD, or } \\
D M+R F\end{array}$ & None & 4.5 & NA & $3394(37) \S$ & NA \\
\hline PART $^{24}$ & Ramipril $v$ placebo & 617 & CHD or CVD & None & 4.7 & $73(16)$ & $119(19)$ & $31(5) \Uparrow$ \\
\hline PROGRESS ${ }^{25}$ & $\begin{array}{l}\text { Perindopril } \\
\text { (+/-indapamide) } v \\
\text { placebo(s) }\end{array}$ & 6105 & $\begin{array}{l}\text { Cerebrovascular } \\
\text { disease }\end{array}$ & None & 3.9 & $78(24)$ & $1172(19)$ & NA \\
\hline $\mathrm{SCAT}^{26}$ & Enalapril v placebo & 460 & $\mathrm{CHD}$ & None & 4 & $68(13)$ & $115(26)$ & NA \\
\hline PREVEND-IT ${ }^{27}$ & Fosinopril $v$ placebo & 864 & Microalbuminuria & $\begin{array}{l}\text { Creatinine } \\
\text { clearance }<60 \% \text { of } \\
\text { normal age adjusted } \\
\text { value }\end{array}$ & 3.8 & $76(12)$ & $70(8)$ & $7(0.8) \dagger$ \\
\hline ADVANCE $^{28}$ & $\begin{array}{l}\text { Perindopril } \\
\text { (+indapamide) } v \\
\text { placebos }\end{array}$ & 11140 & DM & None & 4.3 & $78(25)$ & $2139(19)$ & $406(4)^{\star \star}$ \\
\hline PEACE $^{15}$ & Trandolapril $v$ placebo & 8290 & $\mathrm{CHD}$ & $\mathrm{sCr}>177 \mu \mathrm{mol} / \mathrm{L}$ & 4.8 & $78(19)$ & $1355(16)$ & NA \\
\hline \multicolumn{9}{|c|}{ Calcium antagonist $v$ placebo } \\
\hline BENEDICT $^{21}$ & Verapamil $v$ placebo & 605 & $\begin{array}{l}\mathrm{HBP}+\mathrm{DM} \\
\text { +nephropathy }\end{array}$ & $\mathrm{sCr}>133 \mu \mathrm{mol} / \mathrm{L}$ & 3.6 & $81(15)$ & $43(7)$ & $0(0) \dagger$ \\
\hline PREVENT $^{29}$ & Amlodipine $v$ placebo & 825 & $\mathrm{CHD}$ & None & 3 & $67(13)$ & $249(30)$ & $72(9)$ \\
\hline SYST-EUR ${ }^{30}$ & Nitrendipine $v$ placebo & 4695 & $\mathrm{HBP} \geq 60$ years & $\mathrm{sCr}>180 \mu \mathrm{mol} / \mathrm{L}$ & 2.6 & $69(18)$ & $1,563(33)$ & $109(2) \rrbracket$ \\
\hline
\end{tabular}

$\mathrm{ACE}=$ angiotensin converting enzyme; $\mathrm{CHD}=$ coronary heart disease; $\mathrm{CVD}=$ cardiovascular disease; $\mathrm{DM}=$ diabetes mellitus; $\mathrm{HBP}=$ high blood pressure; $\mathrm{sCr}=\mathrm{serum}$ creatinine.

${ }^{*}$ No of all randomised participants.

†Proteinuria defined as urinary albumin excretion $\geq 200 \mu \mathrm{g} / \mathrm{min}$ or $\geq 300 \mathrm{mg} /$ day.

¥Proteinuria defined as urinary albumin concentration $\geq 200 \mathrm{mg} / \mathrm{L}$.

§Mean eGFR and \% of eGFR $<65 \mathrm{~mL} / \mathrm{min}$, estimated by Cockcroft-Gault formula (HOPE).

IProteinuria defined as dipstick test $1+$ or more.

**Proteinuria defined as urinary albumin creatinine ratio $\geq 300 \mu \mathrm{g} / \mathrm{mg}$. 
Table 2/ Characteristics of included trials comparing more intensive and less intensive regimens to treat raised blood pressure in patients with chronic kidney disease

\begin{tabular}{|c|c|c|c|c|c|c|c|c|c|}
\hline Trial & $\begin{array}{l}\text { Treatment } \\
\text { comparison }\end{array}$ & No* & $\begin{array}{c}\text { Trial } \\
\text { design }\end{array}$ & Entry criteria & $\begin{array}{l}\text { Kidney function } \\
\text { exclusion } \\
\text { criteria }\end{array}$ & $\begin{array}{l}\text { Follow-up } \\
\text { (years) }\end{array}$ & $\begin{array}{l}\text { Mean (SD) eGFR } \\
\left(\mathrm{mL} / \mathrm{min} / 1.73 \mathrm{~m}^{2}\right)\end{array}$ & $\begin{array}{c}\text { No (\%) with } \\
\text { eGFR }<60\end{array}$ & $\begin{array}{l}\text { No }(\%) \text { with } \\
\text { proteinuria }\end{array}$ \\
\hline $\operatorname{ABCD}(H)^{31}$ & $\begin{array}{l}\mathrm{DBP} \leq 75 \mathrm{~mm} \mathrm{Hg} v \\
\leq 90 \mathrm{~mm} \mathrm{Hg}\end{array}$ & 470 & Open & $\mathrm{HBP}+\mathrm{DM}$ & $\mathrm{sCr}>265 \mu \mathrm{mol} / \mathrm{L}$ & 5.3 & $70(16)$ & $120(26)$ & $89(19) \dagger$ \\
\hline $\mathrm{ABCD}(\mathrm{N})^{32}$ & $\begin{array}{l}\text { DBP } 10 \mathrm{~mm} \mathrm{Hg} \\
\text { below baseline } v \\
80-89 \mathrm{~mm} \mathrm{Hg}\end{array}$ & 480 & Open & DM & $\mathrm{sCr}>265 \mu \mathrm{mol} / \mathrm{L}$ & 5.3 & $70(17)$ & $137(29)$ & $51(11) \dagger$ \\
\hline $\mathrm{HOT}^{33}$ & $\begin{array}{l}\text { DBP } \leq 80 \mathrm{~mm} \mathrm{Hg} v \\
\leq 85 \text { or } \leq 90 \mathrm{~mm} \mathrm{Hg}\end{array}$ & 18790 & Open¥ & HBP & None & 3.8 & $75(19)$ & 3619 (19) & NA \\
\hline UKPDS-HDS ${ }^{34}$ & $\begin{array}{l}\mathrm{DBP}<85 \mathrm{~mm} \mathrm{Hg} v \\
<105 \mathrm{~mm} \mathrm{Hg}\end{array}$ & 1148 & Open & $\mathrm{HBP}+\mathrm{DM}$ & $\mathrm{sCr}>175 \mu \mathrm{mol} / \mathrm{L}$ & 8.4 & $82(19)$ & $103(9)$ & NA \\
\hline $\mathrm{AASK}^{45}$ & $\begin{array}{l}\text { MAP } \leq 92 \mathrm{~mm} \mathrm{Hg} v \\
102-107 \mathrm{~mm} \mathrm{Hg}\end{array}$ & 1094 & Open & $\begin{array}{l}\text { HBP+nephropathy, } \\
\text { Afr }\end{array}$ & $\begin{array}{c}\text { GFR }<20 \\
\mathrm{~mL} / \mathrm{min} / 1.73 \mathrm{~m}^{2}\end{array}$ & 4.1 & $46(13) \S$ & $1094(100) \S$ & NA \\
\hline
\end{tabular}

Afr=African American; $C V D=$ cardiovascular disease; $\mathrm{DB}=$ double blind; $\mathrm{DBP}=$ diastolic blood pressure; $\mathrm{DM}=$ diabetes mellitus; $\mathrm{HBP}=\mathrm{high}$ blood pressure; $\mathrm{MAP}=$ mean arterial pressure; $\mathrm{sCr}=$ serum creatinine.

${ }^{*}$ No of all randomised participants.

†Proteinuria defined as urinary albumin excretion $>200 \mu \mathrm{g} / \mathrm{min}$ or $>300 \mathrm{mg} / \mathrm{day}$.

‡PROBE (Prospective, Randomized, Open with Blinded Endpoint evaluation) design trials.

§Mean eGFR and \% of eGFR $<65 \mathrm{~mL} / \mathrm{min}$, estimated by 125 -iothalamate clearance (AASK). 
Table 3| Characteristics of included trials comparing regimens based on different drugs to treat raised blood pressure in patients with chronic kidney disease

\begin{tabular}{|c|c|c|c|c|c|c|c|c|c|}
\hline Trial & $\begin{array}{l}\text { Treatment } \\
\text { comparison }\end{array}$ & $\mathrm{No}^{*}$ & $\begin{array}{c}\text { Trial } \\
\text { design }\end{array}$ & Entry criteria & $\begin{array}{l}\text { Kidney function } \\
\text { exclusion } \\
\text { criteria }\end{array}$ & $\begin{array}{l}\text { Follow-up } \\
\text { (years) }\end{array}$ & $\begin{array}{l}\text { Mean (SD) eGFR } \\
\left(\mathrm{mL} / \mathrm{min} / 1.73 \mathrm{~m}^{2}\right)\end{array}$ & $\begin{array}{l}\text { No (\%) with } \\
\text { eGFR <60 }\end{array}$ & $\begin{array}{l}\text { No (\%) with } \\
\text { proteinuria }\end{array}$ \\
\hline \multicolumn{10}{|c|}{ ACE inhibitor $v$ diuretic or $\beta$ blocker } \\
\hline ALLHAT $^{35}$ & $\begin{array}{l}\text { Lisinopril } v \\
\text { chlorthalidone }\end{array}$ & 24309 & DB & $\mathrm{HBP}+\mathrm{RF}$ & $\mathrm{sCr}>177 \mu \mathrm{mol} / \mathrm{L}$ & 4.9 & $78(20)$ & $4163(18)$ & NA \\
\hline ANBP2 $2^{36}$ & $\begin{array}{l}\text { Enalapril } v \\
\text { hydrochlorothiazide }\end{array}$ & 6083 & Opent & HBP, age $65-84$ & $\mathrm{sCr}>221 \mu \mathrm{mol} / \mathrm{L}$ & 4.1 & $68(15)$ & $1860(31)$ & NA \\
\hline $\mathrm{CAPPP}^{37}$ & $\begin{array}{l}\text { Captopril } v \beta \text { blocker or } \\
\text { diuretic }\end{array}$ & 10985 & Open† & HBP & $\mathrm{sCr}>150 \mu \mathrm{mol} / \mathrm{L}$ & 6.1 & $78(15)$ & $1069(10)$ & $438(4) \ddagger$ \\
\hline STOP- $2^{38}$ & $\begin{array}{l}\text { Enalapril or lisinopril } v \\
\text { atenolol or metoprolol } \\
\text { or pindolol or } \\
\text { hydrochlorothiazide + } \\
\text { amiloride }\end{array}$ & 4418 & Opent & HBP, age 70-84 & None & 5 & $66(15)$ & $1526(35)$ & NA \\
\hline UKPDS-HDS ${ }^{39}$ & Captopril $v$ atenolol & 758 & $\mathrm{DB}$ & $\mathrm{HBP}+\mathrm{DM}$ & $\mathrm{sCr}>175 \mu \mathrm{mol} / \mathrm{L}$ & 8.4 & $83(19)$ & $68(9)$ & NA \\
\hline AASK $\S^{45}$ & Ramipril $v$ metoprolol & 877 & DB & $\begin{array}{l}\text { HBP+nephropathy, } \\
\text { Afr }\end{array}$ & $\begin{array}{c}\text { GFR }<20 \\
\mathrm{~mL} / \mathrm{min} / 1.73 \mathrm{~m}^{2}\end{array}$ & 4.1 & $46(13) \uparrow$ & $877(100) \uparrow$ & NA \\
\hline \multicolumn{10}{|c|}{ Calcium antagonist $v$ diuretic or $\beta$ blocker } \\
\hline $\mathrm{ALLHT}^{35}$ & $\begin{array}{l}\text { Amlodipine } v \\
\text { chlorthalidone }\end{array}$ & 24303 & $\mathrm{DB}$ & $\mathrm{HBP}+\mathrm{RF}$ & $\mathrm{sCr}>177 \mu \mathrm{mol} / \mathrm{L}$ & 4.9 & $78(20)$ & $4149(18)$ & NA \\
\hline $\mathrm{ELSA}^{40}$ & Lacidipine $v$ atenolol & 2334 & $\mathrm{DB}$ & HBP & None & 4 & $80(18)$ & $215(9)$ & $11(0.5)+\dagger$ \\
\hline NICS-EH ${ }^{41}$ & $\begin{array}{l}\text { Nicardipine } v \\
\text { trichlormethiazide }\end{array}$ & 429 & DB & $\mathrm{HBP}$, age $\geq 60$ & None & 5 & $90(27)$ & $42(10)$ & NA \\
\hline NORDIL $^{42}$ & $\begin{array}{l}\text { Diltiazem } v \beta \text { blocker or } \\
\text { diuretic }\end{array}$ & 10881 & Opent & HBP & None & 5 & 74 (15) & $1664(15)$ & NA \\
\hline STOP- $-2^{38}$ & $\begin{array}{l}\text { Felodipine or isradipine } \\
\text { vatenolol or metoprolol } \\
\text { or pindolol or } \\
\text { hydrochlorothiazide + } \\
\text { amiloride }\end{array}$ & 4409 & Opent & HBP, age 70-84 & None & 5 & $66(15)$ & $1467(33)$ & NA \\
\hline $\mathrm{VHAS}^{43}$ & $\begin{array}{l}\text { Verapamil } v \\
\text { chlorthalidone }\end{array}$ & 1414 & DB/Open & HBP & $\mathrm{sCr}>150 \mu \mathrm{mol} / \mathrm{L}$ & 2 & $82(24)$ & $134(10)$ & NA \\
\hline AASK\$ $\S^{45}$ & $\begin{array}{l}\text { amlodipine } v \\
\text { metoprolol }\end{array}$ & 658 & DB & $\begin{array}{l}\text { HBP+nephropathy, } \\
\text { Afr }\end{array}$ & $\begin{array}{c}\text { GFR }<20 \\
\mathrm{~mL} / \mathrm{min} / 1.73 \mathrm{~m}^{2}\end{array}$ & 4.1 & 46 (13)ף & $658(100) \uparrow$ & NA \\
\hline \multicolumn{10}{|c|}{ ACE inhibitor $v$ calcium antagonist } \\
\hline $\mathrm{ABCD}(\mathrm{H})^{31}$ & Enalapril $v$ nisoldipine & 470 & DB & $\mathrm{HBP}+\mathrm{DM}$ & $\mathrm{sCr}>265 \mu \mathrm{mol} / \mathrm{L}$ & 5.3 & $70(16)$ & $120(26)$ & $89(19)^{\star \star}$ \\
\hline $\mathrm{ABCD}(\mathrm{N})^{32}$ & Enalapril $v$ nisoldipine & 480 & $\mathrm{DB}$ & DM & $\mathrm{sCr}>265 \mu \mathrm{mol} / \mathrm{L}$ & 5.3 & $70(17)$ & $137(29)$ & $51(11)^{* \star}$ \\
\hline ALLHAT $^{35}$ & Lisinopril $v$ amlodipine & 18102 & $\mathrm{DB}$ & $\mathrm{HBP}+\mathrm{CVD} \mathrm{RF}$ & $\mathrm{sCr}>177 \mu \mathrm{mol} / \mathrm{L}$ & 4.9 & $78(20)$ & $3056(18)$ & NA \\
\hline BENEDICT $^{21}$ & $\begin{array}{l}\text { Trandolapril v } \\
\text { verapamil }\end{array}$ & 605 & DB & $\mathrm{HBP}+\mathrm{DM}$ & $\mathrm{sCr}>133 \mu \mathrm{mol} / \mathrm{L}$ & 3.6 & $81(15)$ & $36(6)$ & $0(0)^{* *}$ \\
\hline JMIC-B $^{44}$ & $\begin{array}{l}\text { ACE inhibitor } v \\
\text { nifedipine }\end{array}$ & 1650 & Open† & $\mathrm{HBP}+\mathrm{CHD}$ & $\mathrm{sCr}>177 \mu \mathrm{mol} / \mathrm{L}$ & 3 & $89(27)$ & $166(12)$ & NA \\
\hline STOP-2 $2^{38}$ & $\begin{array}{l}\text { Enalapril or lisinopril } v \\
\text { felodipine or isradipine }\end{array}$ & 4401 & Opent & HBP, age 70-84 & None & 5 & $66(15)$ & $1507(34)$ & NA \\
\hline AASK§ $\S^{45}$ & Ramipril $v$ amlodipine & 653 & $\mathrm{DB}$ & $\begin{array}{l}\text { HBP+nephropathy, } \\
\text { Afr }\end{array}$ & $\begin{array}{c}\text { GFR }<20 \\
\mathrm{~mL} / \mathrm{min} / 1.73 \mathrm{~m}^{2}\end{array}$ & 4.1 & 46 (13)ף & $653(100) \uparrow$ & NA \\
\hline
\end{tabular}

$\mathrm{ACE}=$ angiotensin converting enzyme; Afr=African American; $\mathrm{CHD}=$ coronary heart disease; $\mathrm{CVD}=$ cardiovascular disease; $\mathrm{DB}=$ double blind; $\mathrm{DM}=$ diabetes mellitus; $\mathrm{HBP}=$ high blood pressure; $\mathrm{s} \mathrm{Cr}=$ serum creatinine.

${ }^{*} \mathrm{No}$ of all randomised participants.

†PROBE (Prospective, Randomized, Open with Blinded Endpoint evaluation) design trials.

†Proteinuria defined as dipstick test $1+$ or more.

§AASK trial included for sensitivity analysis, because patients contributed only to reduced eGFR stratum.

IMean eGFR and \% of eGFR $<65 \mathrm{~mL} / \mathrm{min}$, estimated by 125 -iothalamate clearance (AASK).

${ }^{* *}$ Proteinuria defined as urinary albumin excretion $\geq 200 \mu \mathrm{g} / \mathrm{min}$ or $\geq 300 \mathrm{mg} /$ day.

††Proteinuria was defined as urinary albumin excretion more than $500 \mathrm{mg} / \mathrm{L}$. 
Table 4| Mean baseline characteristics and follow-up differences in blood pressure between randomised groups according to different baseline glomerular filtration rate (eGFR)

\begin{tabular}{|c|c|c|c|c|c|c|c|}
\hline \multirow{2}{*}{$\begin{array}{l}\text { Treatment } \\
\text { comparison }\end{array}$} & \multirow[b]{2}{*}{ No $(\%)^{*}$} & \multirow[b]{2}{*}{ Age (years) } & \multirow[b]{2}{*}{ Men (\%) } & \multirow{2}{*}{$\begin{array}{l}\text { Baseline } \mathrm{Cr} \\
(\mathrm{mmol} / \mathrm{L})\end{array}$} & \multirow{2}{*}{$\begin{array}{c}\text { Baseline eGFR } \\
\left(\mathrm{mL} / \mathrm{min} / 1.73 \mathrm{~m}^{2}\right)\end{array}$} & \multicolumn{2}{|c|}{ Systolic/diastolic(mm Hg) } \\
\hline & & & & & & Baseline & During follow-up \\
\hline \multicolumn{8}{|l|}{ All trials } \\
\hline eGFR $\geq 60$ & $121995(80)$ & 63 & 60 & 83 & 81 & $156 / 91$ & $141 / 81$ \\
\hline eGFR $<60$ & $30295(20)$ & 68 & 40 & 115 & 52 & $160 / 90$ & $144 / 80$ \\
\hline \multicolumn{8}{|c|}{ Active treatment $v$ placebo $†$} \\
\hline \multicolumn{8}{|c|}{ ACEI $v$ placebo: } \\
\hline eGFR $\geq 60$ & $42896(79)$ & 62 & 75 & 84 & 82 & $141 / 82$ & $135 / 78$ \\
\hline eGFR $<60$ & $11399(21)$ & 67 & 55 & 117 & 52 & $145 / 82$ & $137 / 77$ \\
\hline \multicolumn{8}{|c|}{ Calcium antagonist $v$ placebo: } \\
\hline eGFR $\geq 60$ & $4252(70)$ & 66 & 49 & 82 & 77 & $164 / 85$ & $151 / 81$ \\
\hline eGFR $<60$ & $1855(30)$ & 70 & 24 & 106 & 52 & $169 / 84$ & $154 / 80$ \\
\hline \multicolumn{8}{|c|}{ More intensive $v$ less intensive regimens } \\
\hline eGFR $\geq 60$ & $16687(81)$ & 60 & 58 & 83 & 81 & $168 / 104$ & $142 / 83$ \\
\hline eGFR $<60$ & $3979(19)$ & 65 & 35 & 114 & 52 & $170 / 104$ & $143 / 83$ \\
\hline \multicolumn{8}{|c|}{ Comparisons of drugs classes } \\
\hline \multicolumn{8}{|c|}{ ACEI $v$ diuretic or $\beta$ blocker: } \\
\hline eGFR $\geq 60$ & $36540(81)$ & 63 & 54 & 83 & 81 & $156 / 90$ & $143 / 83$ \\
\hline eGFR $<60$ & $8686(19)$ & 71 & 38 & 116 & 51 & $162 / 89$ & $146 / 81$ \\
\hline \multicolumn{8}{|c|}{ Calcium antagonist $v$ diuretic or $\beta$ blocker: } \\
\hline eGFR $\geq 60$ & $34838(82)$ & 64 & 53 & 82 & 81 & $159 / 93$ & $144 / 83$ \\
\hline eGFR $<60$ & $7671(18)$ & 70 & 37 & 116 & 52 & $163 / 91$ & $147 / 82$ \\
\hline \multicolumn{8}{|c|}{ ACEI $v$ calcium antagonist: } \\
\hline eGFR $\geq 60$ & $19520(80)$ & 67 & 54 & 82 & 83 & $153 / 87$ & $141 / 80$ \\
\hline eGFR $<60$ & $5022(20)$ & 72 & 41 & 119 & 51 & $161 / 88$ & $147 / 80$ \\
\hline
\end{tabular}

$\mathrm{ACEl}=$ angiotensin converting enzyme inhibitor.

*No of participants with available data on GFR.

†Data for age, sex, baseline SBP, baseline serum creatinine, and baseline eGFR unavailable, and same degree of blood pressure reductions during follow-up in each kidney function group were assumed in HOPE and PEACE. 


\section{Figures}

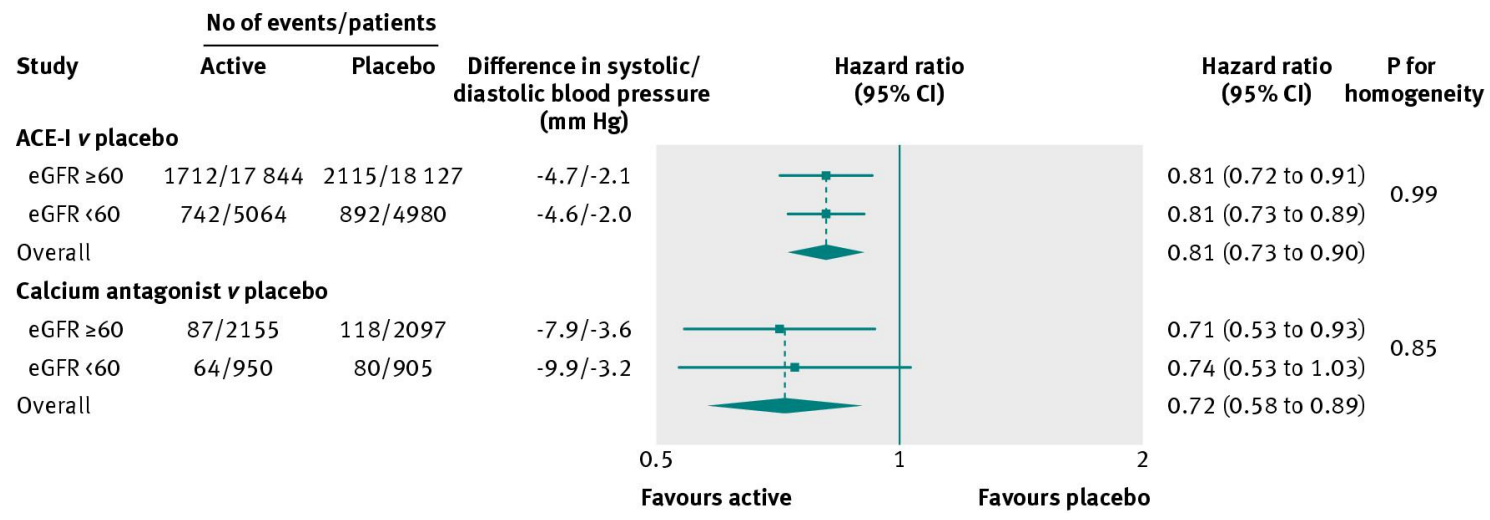

Fig 1 Effects of angiotensin converting enzyme inhibitor or calcium antagonist based regimens $v$ placebo for risk of major cardiovascular events according to kidney function status. $P$ value for homogeneity indicates consistency of effect of treatment regimen among subgroup. Overall mean difference in systolic and diastolic blood pressure during follow-up in actively treated/first listed regimens $v$ control/second listed regimens, calculated by weighting difference observed in each contributing trial by number of patients in trial. Negative values indicate lower mean systolic and diastolic blood pressure during follow-up in actively treated/first listed groups than in control/second listed groups

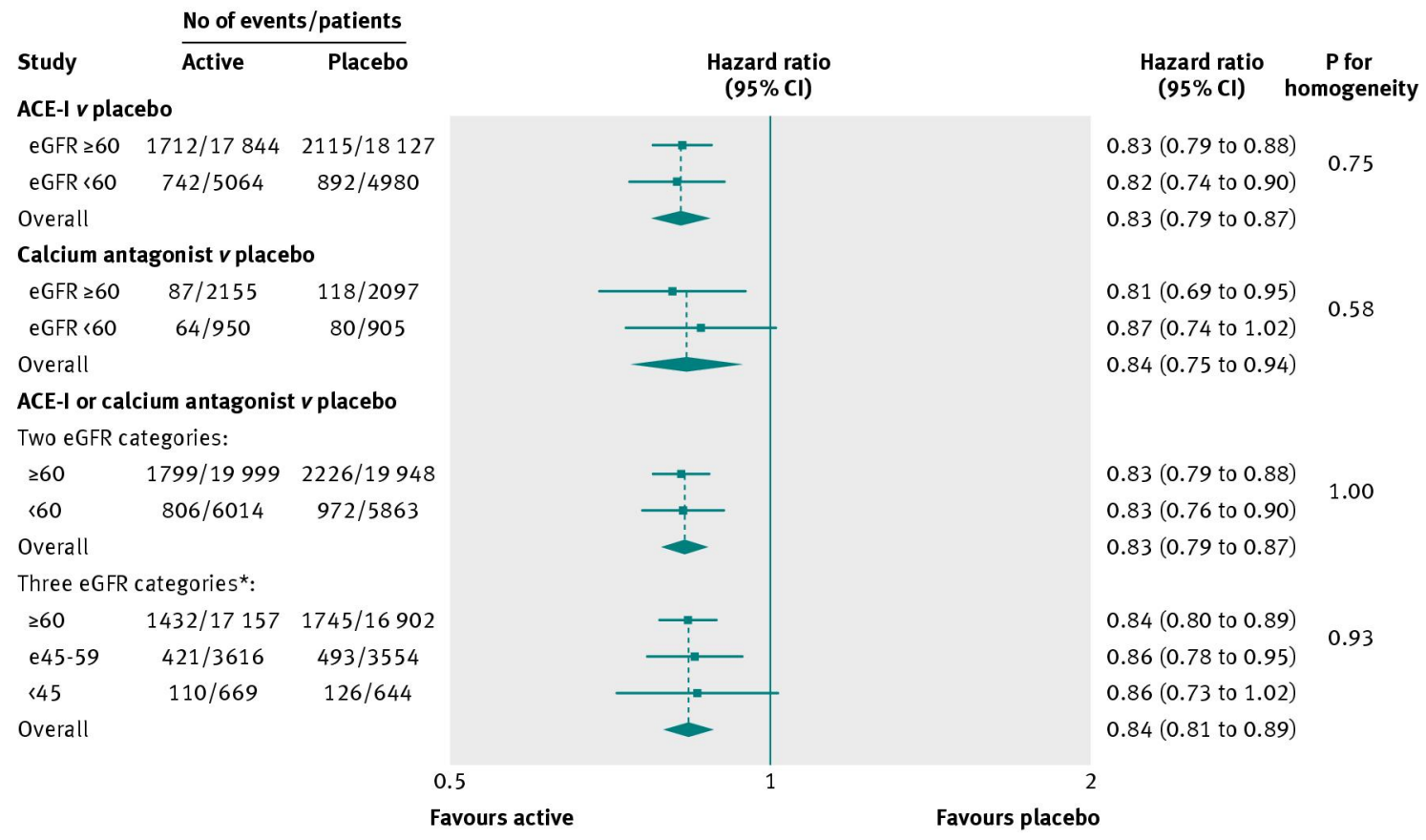

Fig 2 Effects of angiotensin converting enzyme inhibitor or calcium antagonist based regimens $v$ placebo per $5 \mathrm{~mm} H \mathrm{Hg}$ reduction in systolic blood pressure over time on risk of major cardiovascular events according to kidney function status. Pooled estimates estimated with relative risk model weighted for blood pressure reduction. Values show relative risk per 5 $\mathrm{mm} \mathrm{Hg}$ reduction in systolic blood pressure over time. *Data from HOPE trial not available for analysis of three GFR categories 


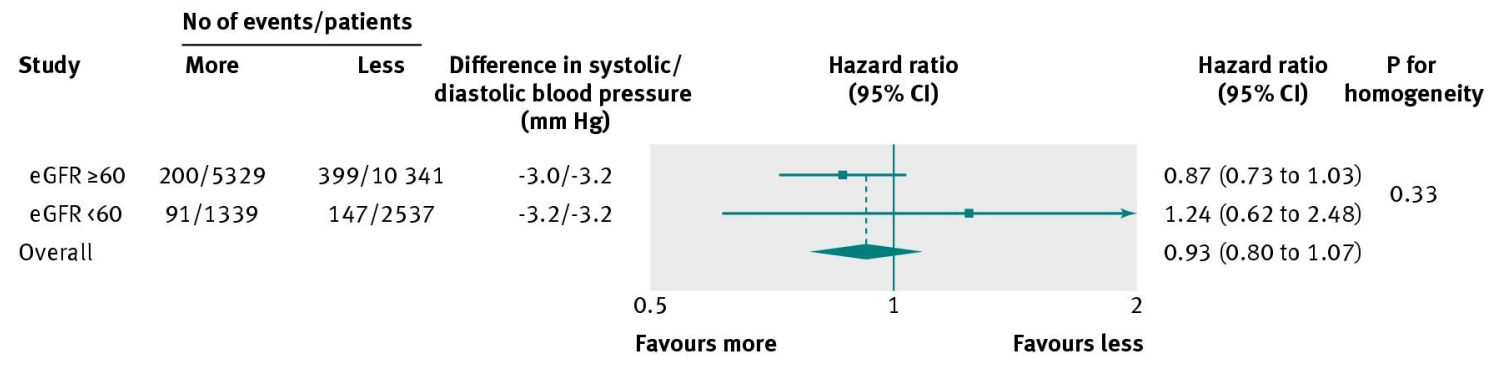

Fig 3 Effects of more intensive $v$ less intensive blood pressure lowering regimens for risk of major cardiovascular events according to kidney function status

\begin{tabular}{|c|c|c|c|c|c|c|}
\hline \multirow[b]{2}{*}{ Study } & \multicolumn{2}{|c|}{ No of events/patients } & \multirow{3}{*}{$\begin{array}{c}\text { Difference in systolic/ } \\
\text { diastolic blood pressure } \\
\text { ( } \mathrm{mm} \mathrm{Hg})\end{array}$} & \multirow{3}{*}{$\begin{array}{c}\text { Hazard ratio } \\
(95 \% \mathrm{Cl})\end{array}$} & \multirow[b]{2}{*}{$\begin{array}{l}\text { Hazard ratio } \\
(95 \% \mathrm{Cl})\end{array}$} & \multirow{3}{*}{$\begin{array}{c}\mathrm{P} \text { for } \\
\text { homogeneity }\end{array}$} \\
\hline & $\begin{array}{c}\text { First } \\
\text { listed }\end{array}$ & $\begin{array}{l}\text { Second } \\
\text { listed } d\end{array}$ & & & & \\
\hline \multicolumn{2}{|c|}{ ACE-I $v$ diuretic $/ \beta$ blocker } & & & & & \\
\hline eGFR $\geq 60$ & $1806 / 15514$ & $2480 / 20353$ & $1.8 / 0.4$ & - & 1.03 (0.97 to 1.10$)$ & \multirow{3}{*}{$\begin{array}{l}\text { 0) } \\
\text { 1) } 0.64 \\
\text { 8) }\end{array}$} \\
\hline eGFR $<60$ & $674 / 3747$ & $933 / 4871$ & $1.3 / 0.2$ & - & $1.00(0.91$ to 1.11$)$ & \\
\hline Overall & & & & b & 1.02 (0.97 to 1.08$)$ & \\
\hline \multicolumn{7}{|c|}{ Calcium antagonist $v$ diuretic $/ \beta$ blocker } \\
\hline eGFR $\geq 60$ & $1739 / 14980$ & $2402 / 19858$ & $1.7 /-0.3$ & 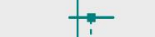 & 1.04 (0.98 to 1.11$)$ & \multirow{2}{*}{ 1) 0.90} \\
\hline eGFR $<60$ & $637 / 3257$ & $887 / 4414$ & $1.5 /-0.4$ & - & 1.05 (0.93 to 1.16$)$ & \\
\hline Overall & & & & $\dot{B}$ & 1.04 (0.99 to 1.10$)$ & \\
\hline \multicolumn{7}{|c|}{ ACE-I $v$ calcium antagonist } \\
\hline eGFR $\geq 60$ & $1411 / 9733$ & $1468 / 9787$ & $0.9 / 0.9$ & $\rightarrow+$ & $0.97(0.90$ to 1.05$)$ & \multirow{3}{*}{$\begin{array}{ll}\text { 5) } & \\
\text { 6) } & 0.71 \\
\text { 3) } & \end{array}$} \\
\hline eGFR $<60$ & $585 / 2545$ & $601 / 2477$ & $0.4 / 0.6$ & - & $0.95(0.85$ to 1.06$)$ & \\
\hline \multirow[t]{3}{*}{ Overall } & & & & $<$ & $0.97(0.91$ to 1.03$)$ & \\
\hline & & & 0.5 & 1 & & \\
\hline & & & Favours & Favou & & \\
\hline
\end{tabular}

Fig 4 Effects of blood pressure lowering regimens based on different drug classes for risk of major cardiovascular events according to kidney function status

Study

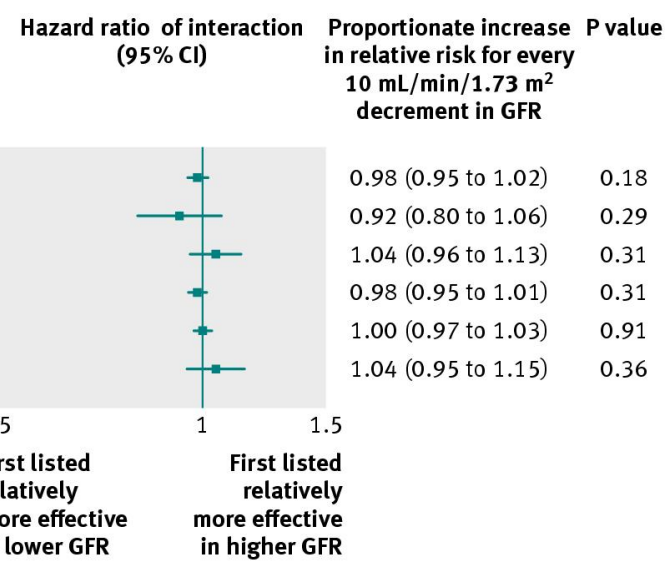

Fig 5 Proportional increase in risk ratio of treatment effect on major cardiovascular events for every $10 \mathrm{~mL} / \mathrm{min} / 1.73 \mathrm{~m}{ }^{2}$ decrement in eGFR 
Reduction in risk for each $5 \mathrm{mmHg}$ reduction in systolic blood pressure

-0 eGFR $\geq 60: 14.2 \%$ (8.6 to $19.5 \%$ )

- o- eGFR $<60: 12.1 \%$ (2.9 to $20.4 \%)$

$P$ for difference in trend of slopes $=0.69$

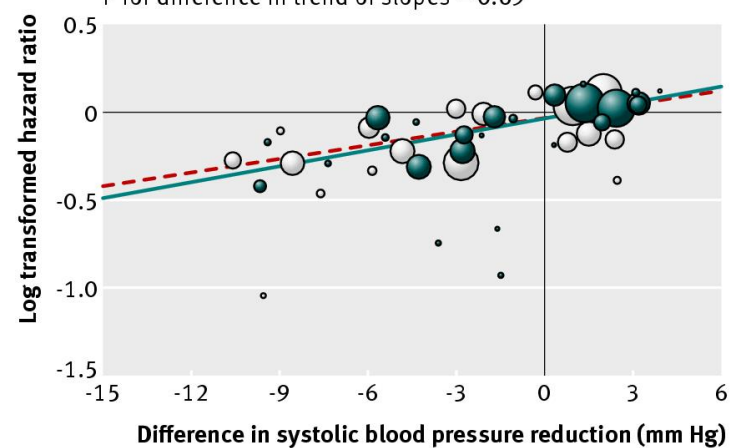

Fig 6 Associations between systolic blood pressure reduction and risk reduction for major vascular events according to kidney function status. Centre of each circle is placed at estimates of risk ratio for each trial. Area of each circle is proportional to variance of log odds ratio. Fitted lines represent summary meta-regressions for total major cardiovascular events. Intercepts were 0.96 (0.93 to 1.01) for eGFR $\geq 60 \mathrm{~mL} / \mathrm{min} / 1.73 \mathrm{~m}^{2}$ and 0.97 (0.89 to 1.04) for eGFR $<60 \mathrm{~mL} / \mathrm{min} / 1.73 \mathrm{~m}{ }^{2}$

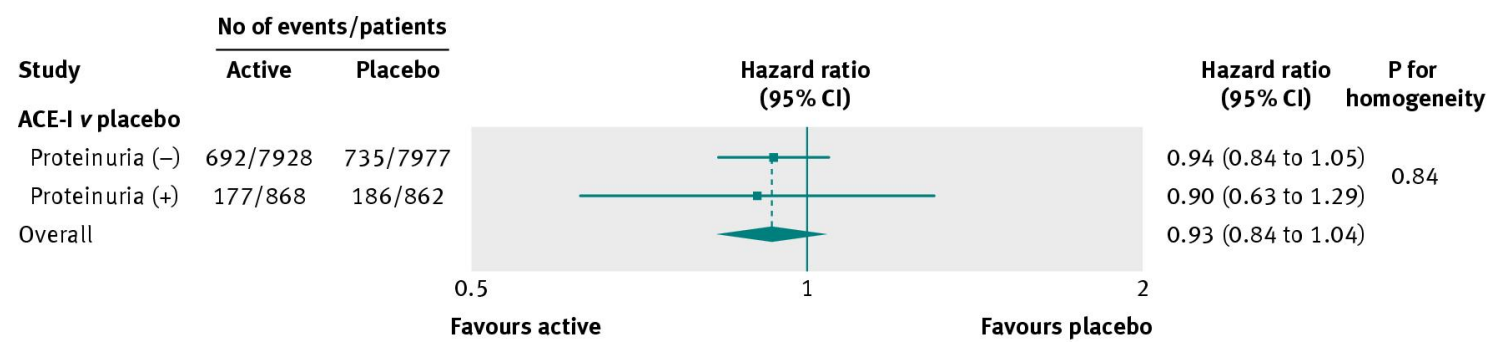

Fig 7 Effects of angiotensin converting enzyme inhibitor or calcium antagonist based regimens $v$ placebo per $5 \mathrm{~mm} \mathrm{Hg}$ reduction in systolic blood pressure over time on risk of major cardiovascular events according to proteinuria status 